\title{
Barriers and facilitators to implementing bubble CPAP to improve neonatal health in sub-Saharan Africa: a systematic review
}

\author{
Mai-Lei Woo Kinshella ${ }^{1}$, Celia R. Walker ${ }^{2}$, Tamanda Hiwa ${ }^{3}$, Marianne Vidler ${ }^{1}$, Alinane Linda Nyondo-Mipando ${ }^{4}$,
} Queen Dube 3,5 , David M. Goldfarb² and Kondwani Kawaza ${ }^{3,5^{*}}$

\author{
* Correspondence: kkawaza@ \\ medcol.mw \\ ${ }^{3}$ Department of Pediatrics and Child \\ Health, College of Medicine, \\ University of Malawi, Blantyre, \\ Malawi \\ ${ }^{5}$ Department of Paediatrics, Queen \\ Elizabeth Central Hospital, Blantyre, \\ Malawi \\ Full list of author information is \\ available at the end of the article
}

\begin{abstract}
Background: Bubble continuous positive airway pressure (CPAP) has been shown to be effective in supporting breathing in newborns with respiratory distress. The factors that influence implementation in resource-constrained settings remain unclear. The objective of this review is to evaluate the barriers and facilitators of CPAP implementation for newborn care at sub-Saharan African health facilities and how different facility levels and types of bubble CPAP systems may impact utilization.

Methods: A systematic search (database inception to July 2019) was performed on MEDLINE Ovid, EMBASE, CINAHL, The Cochrane Central Register of Controlled Trials (CENTRAL, The Cochrane Library), the WHO Regional Database for Africa, African Index Medicus (AIM), African Journals Online, grey literature and the references of relevant articles. Studies that met the inclusion criteria (primary research, bubble CPAP implementation with neonates $\leq 28$ days old at a health facility in sub-Saharan Africa) were included in the review and assessed with National Heart, Lung, and Blood Institute of the National Institutes of Health $(\mathrm{NIH})$ quality assessment tools. The review protocol was published to PROSPERO (CRD42018116082).
\end{abstract}

Results: Seventeen studies were included in the review. Reliable availability of equipment, effectively informing and engaging caregivers and staffing shortages were frequently mentioned barriers to the implementation of bubble CPAP. Understaffed neonatal units and high turnover of nurses and doctors compromised effective training. Provider-to-provider clinical mentorship models as well as affordability and cost-effectiveness of innovative bubble CPAP systems were identified as frequently mentioned facilitators of implementation.

Conclusions: With a strong recommendation by the World Health Organization for its use with premature infants with respiratory distress, it is important to understand the barriers and facilitators that can inform the implementation of bubble CPAP. More research is needed into health system factors that can support or impede the use of this potentially promising intervention.

Keywords: Bubble continuous positive airway pressure (CPAP), Sub-Saharan Africa, Neonates, Implementation, Low-resource settings 


\section{Introduction}

Globally, there have been significant declines in infant mortality but rates of neonatal mortality are declining at a slower pace than among older infants and children [1]. Although the third Sustainable Development Goal (SDG-3) aims to reduce under-five mortality rates to fewer than 25 per 1000 live births and neonatal mortality rates to fewer than 12 per 1000 by the year 2030, a recent study found that if the slow trend in neonatal mortality reduction continues, only two out of the 31 sub-Saharan African countries are predicted to achieve SDG-3 targets [2]. Among newborns in sub-Saharan Africa, one in every 36 neonates die within the first month, a staggering inequality compared to one in 333 in high-income countries (HICs) [3]. Preterm birth complications are a leading cause of neonatal death [1] and a review found that nine of the 11 countries globally with estimated preterm birth rates of $15 \%$ or more were in subSaharan Africa [4]. With an estimated average pre-term birth rate at $12.3 \%$ across the sub-Saharan Africa region (12.3\%), there is a need to effectively address accompanying complications in order to reduce the burden of neonatal deaths [1, 4]. Preterm newborns often have underdeveloped respiratory systems, with more than $50 \%$ of infants born before 31 weeks gestation developing respiratory distress syndrome (RDS) [5].

Newborns with RDS can be managed effectively with breathing support, such as mechanical ventilation or continuous positive airway pressure (CPAP), as well as surfactant replacement therapy [6]. CPAP is strongly recommended by the World Health Organization (WHO) for the treatment of preterm newborns with RDS [7]. CPAP is a simple, non-invasive form of respiratory support requiring less advanced technical expertise than mechanical ventilation, an invasive procedure involving endotracheal intubation or tracheostomy tube insertion [8-11]. Although CPAP is widely recommended for managing respiratory distress and has been utilized in high-income countries (HICs) for decades, hospitals in resource-limited settings still experience challenges in its implementation. Conventional CPAP machines, while less costly than mechanical ventilation, are still not economically sustainable in most low- and middleincome countries (LMICs). Bubble CPAP provides a potential solution, as a safe and cost-effective way for delivering CPAP in LMICs [8]. Bubble CPAP safely regulates air pressure by submerging the end of the expiration tubing into water, with the depth of the tube in the water determining the pressure in the system [8-12]. This maintains a volume of air in the lungs (functional residual lung capacity) to support the newborn's spontaneous breathing [8-12]. A systematic review demonstrated that when bubble CPAP is utilized effectively, it can reduce the need for mechanical ventilation by 30 $50 \%$ with no increase in mortality [8].

Although there is evidence suggesting that bubble CPAP is an efficacious, safe, costeffective device to support neonatal breathing, there is still a lack of knowledge regarding factors influencing implementation in limited-resource settings [13]. Consequently, the primary objective of this systematic review is to evaluate known barriers and facilitators to the implementation, utilization and sustainability of bubble CPAP for neonates at health facilities in sub-Saharan Africa. Secondary objectives of the review explore the varying types of devices and the different hospital settings where bubble CPAP are used. The secondary objectives are firstly, to scope and document the different types of bubble CPAP and facility levels implementing bubble CPAP in sub-Saharan Africa and secondly, to evaluate barriers and facilitators of bubble CPAP for neonates at health 
facilities in sub-Saharan Africa by health facility and device type. The third secondary objective is to understand the efficacy and safety of bubble CPAP for neonates at health facilities in sub-Saharan Africa by health facility and device type. Based on the strong recommendation by the $\mathrm{WHO}$, it is important to understand the barriers and facilitators that can inform effective bubble CPAP implementation in resource-constrained settings such as in many sub-Saharan hospitals, where bubble CPAP therapy is a critical need.

\section{Methodology}

Searches were undertaken on MEDLINE Ovid, EMBASE, CINAHL, The Cochrane Central Register of Controlled Trials (CENTRAL, The Cochrane Library), the WHO Regional Database for Africa, African Index Medicus (AIM) and the African Journals Online database to July 2019 by the primary (MWK) reviewer, with no limits applied to the year of publication. Based on the PICOS research framework (Table 1), search terms broadly included infants, neonates, respiratory distress syndrome (RDS), subSaharan Africa and bubble CPAP (see Additional file 1). Results were then manually screened for implementation, utilization and health facility to prevent missing relevant studies in the original search that did not include these keywords. Grey literature, including programme reports and dissertations, was searched on Google and Google Scholar and conference proceedings authors were contacted directly by the primary researcher. Reference lists of all primary studies were reviewed for additional references.

Titles and/or abstracts of studies were independently screened by the primary and secondary reviewers (MWK and CRW) according to the eligibility criteria (Table 2). We included studies that self-identified as a bubble CPAP device though recognize that a recent study has shown that a low-cost standalone system, Pumani, does not fully follow the mechanisms of a bubble CPAP device [14]. However, because this study focuses on implementation factors and Pumani has been updated in response to the study by Falk and colleagues, we have elected to include it in our review as the broader picture of health system barriers and facilitators remain similar. Discussions of efficacy and safety will present separate data for Pumani device. Barriers were defined as implementation factors that hindered CPAP use within local contexts while facilitators were implementation factors that supported CPAP use as self-reported by studies. Reviewers compared their results to reach consensus and ties were resolved by a third reviewer (THM). Full text of these studies was then independently reviewed by the primary and secondary reviewers, with the third reviewer (THM) providing an independent assessment in any disagreements regarding eligibility until consensus was reached. Details about the study method, sample size, country, facility type, bubble CPAP type,

Table 1 PICOS research framework

\begin{tabular}{ll}
\hline Population & Neonates $\leq 28$ days \\
Intervention & Bubble CPAP \\
Context & Secondary or tertiary health facilities in sub-Saharan Africa \\
Comparisons & Non-bubble CPAP, other respiratory support interventions, no respiratory support interventions, \\
& N/A \\
Outcome & Enablers and barriers of bubble CPAP, survival to discharge rates \\
Study & All study designs \\
\hline
\end{tabular}


Table 2 Eligibility criteria

\begin{tabular}{|c|c|}
\hline Inclusion criteria & Exclusion criteria \\
\hline $\begin{array}{l}\text { - Discussed implementation and/or utilization of self- } \\
\text { identified bubble CPAP systems with neonates ( } \leq 28 \\
\text { days old) } \\
\text { - At a health facility in sub-Saharan Africa } \\
\text { - Randomized controlled trials, quasi-experimental } \\
\text { studies, observational and exploratory studies, case } \\
\text { studies, economic evaluations, programme reports and } \\
\text { clinical charting }\end{array}$ & $\begin{array}{l}\text { - Neonatal data not separated from older infants older } \\
\text { than } 28 \text { days, older children and/or adults } \\
\text { - Studies that do not specify bubble CPAP from other } \\
\text { forms of CPAP or neonatal respiratory support } \\
\text { systems } \\
\text { - Studies without primary data collection on using } \\
\text { bubble CPAP in a health facility } \\
\text { - Study protocols, literature reviews, conference } \\
\text { proceedings, letters to the editor, opinion papers, } \\
\text { editorials and abstracts } \\
\text { - Not in English }\end{array}$ \\
\hline
\end{tabular}

outcomes, complications, barriers, and facilitators were extracted into a data extraction sheet. The ROBINS-I tool was initially planned for quality assessment but its focus on non-randomized studies was not suited to the diversity of studies found in the search. The focus of the ROBINS-1 tool is on intervention studies [15], which was too narrow of a scope to accommodate the variety of observational studies that highlight implementation aspects. The study quality assessment tools of the National Heart, Lung, and Blood Institute of the National Institutes of Health (NIH) for quality assessment of case series, observational cohort and cross-sectional studies, before-after studies with no control group and controlled intervention studies were used to assess the quality of included studies [16, 17]. The review protocol was published to PROSPERO (CRD42018116082) [18].

\section{Results}

Seventeen studies that discussed using bubble CPAP at a health facility in sub-Saharan Africa with neonates were found in the search (Fig. 1, Table 3). This included six case studies or series of neonates who received bubble CPAP [19, 20, 22, 23, 29, 34], four observational cohort or cross-sectional studies [26, 30, 31, 33], three uncontrolled before-and-after studies [12, 25, 32] and four case-control intervention studies that compared novel use of bubble CPAP systems or implementation components with local

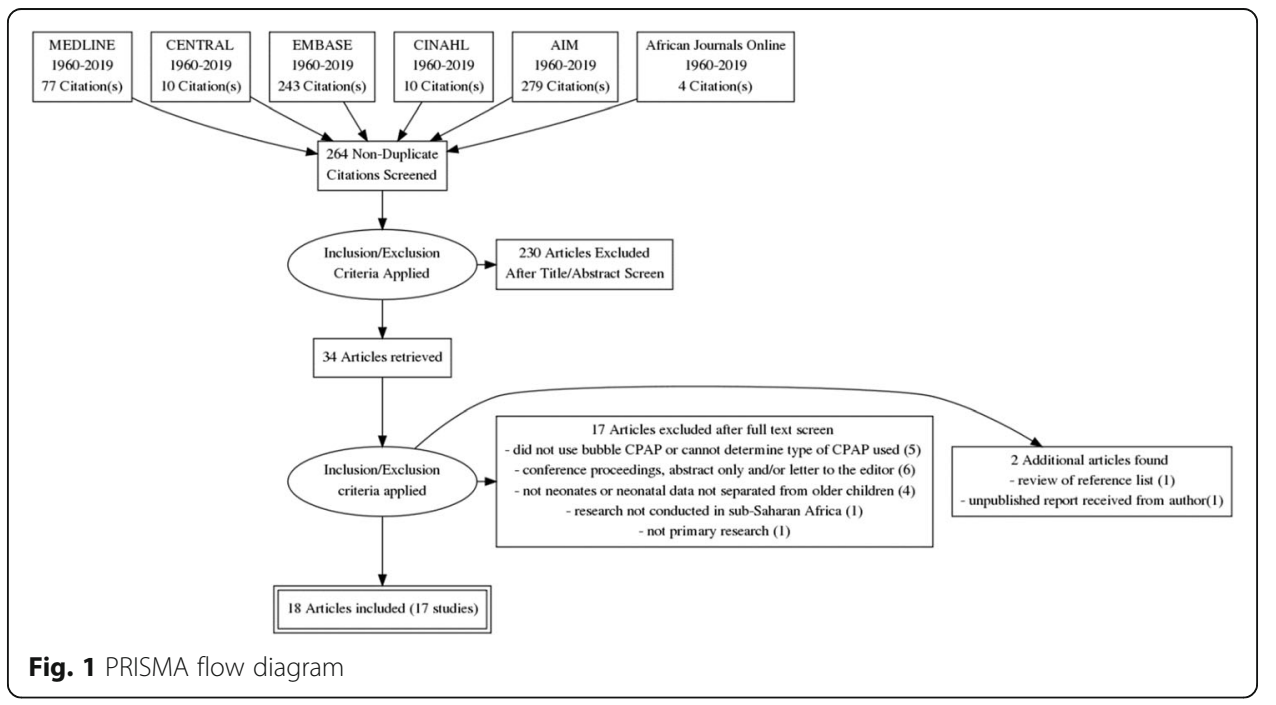


Table 3 Studies included in the review

\begin{tabular}{|c|c|c|c|c|c|c|}
\hline Reference & Research design & Sample & Location & $\begin{array}{l}\text { Facility } \\
\text { level }\end{array}$ & Device used & $\begin{array}{l}\text { Quality } \\
\text { assessment }\end{array}$ \\
\hline $\begin{array}{l}\text { Abdulkadir } \\
\text { et al. [19] }\end{array}$ & $\begin{array}{l}\text { Descriptive case } \\
\text { study }\end{array}$ & $\begin{array}{l}\text { Male newborn (1 h } \\
\text { old) with idiopathic } \\
\text { respiratory distress } \\
\text { syndrome }\end{array}$ & $\begin{array}{l}\text { Ahmadu } \\
\text { Bello } \\
\text { University } \\
\text { Teaching } \\
\text { Hospital } \\
\text { (ABUTH), } \\
\text { Nigeria }\end{array}$ & Tertiary & $\begin{array}{l}\text { Bubble CPAP } \\
\text { system not } \\
\text { described }\end{array}$ & $\begin{array}{l}\text { Poor } \\
\text { quality }\end{array}$ \\
\hline $\begin{array}{l}\text { Abdulkadir } \\
\text { et al. [20] }\end{array}$ & $\begin{array}{l}\text { Descriptive case } \\
\text { series of neonates } \\
\text { who received nasal } \\
\text { bubble CPAP }\end{array}$ & $\begin{array}{l}20 \text { spontaneously } \\
\text { breathing } \\
\text { newborns with } \\
\text { respiratory distress } \\
\text { over } 1 \text {-year period } \\
\text { from } 1 \text { June } 2012 \\
\text { to } 31 \text { May } 2013\end{array}$ & $\begin{array}{l}\text { Ahmadu } \\
\text { Bello } \\
\text { University } \\
\text { Teaching } \\
\text { Hospital } \\
\text { (ABUTH), } \\
\text { Nigeria }\end{array}$ & Tertiary & $\begin{array}{l}\text { Improvised } \\
\text { water bottle } \\
\text { system }\end{array}$ & Fair quality \\
\hline $\begin{array}{l}\text { Amadi } \\
\text { et al. [21] }\end{array}$ & $\begin{array}{l}\text { Quasi-experimental } \\
\text { study comparing } \\
\text { politeCPAP } \\
\text { outcomes with } \\
\text { standard care } \\
\text { (improvised bubble } \\
\text { CPAP system) }\end{array}$ & $\begin{array}{l}57 \text { neonates with } \\
\text { RDS who met } \\
\text { eligibility from } \\
\text { three hospitals, } \\
\text { dates unknown }\end{array}$ & $\begin{array}{l}\text { Multiple } \\
\text { locations, } \\
\text { Nigeria }\end{array}$ & Tertiary & $\begin{array}{l}\text { Low-cost } \\
\text { standalone } \\
\text { system- } \\
\text { politeCPAP }\end{array}$ & $\begin{array}{l}\text { Poor } \\
\text { quality }\end{array}$ \\
\hline $\begin{array}{l}\text { Audu et al. } \\
\text { [22] }\end{array}$ & $\begin{array}{l}\text { Descriptive case } \\
\text { series of neonates } \\
\text { who received nasal } \\
\text { bubble CPAP }\end{array}$ & $\begin{array}{l}48 \text { babies admitted } \\
\text { into newborn unit } \\
\text { with respiratory } \\
\text { distress over a 6- } \\
\text { month period, } \\
\text { dates unknown }\end{array}$ & $\begin{array}{l}\text { National } \\
\text { Hospital } \\
\text { Abuja, } \\
\text { Nigeria }\end{array}$ & Tertiary & $\begin{array}{l}\text { Improvised } \\
\text { water bottle } \\
\text { system }\end{array}$ & Fair quality \\
\hline $\begin{array}{l}\text { Brown } \\
\text { et al. [23] }\end{array}$ & $\begin{array}{l}\text { Descriptive case } \\
\text { study }\end{array}$ & $\begin{array}{l}\text { A full-term neonate } \\
\text { with respiratory dis- } \\
\text { tress caused by } \\
\text { congenital } \\
\text { pneumonia }\end{array}$ & $\begin{array}{l}\text { Queen } \\
\text { Elizabeth } \\
\text { Central } \\
\text { Hospital, } \\
\text { Malawi }\end{array}$ & Tertiary & $\begin{array}{l}\text { Low-cost } \\
\text { standalone } \\
\text { system- } \\
\text { Pumani }\end{array}$ & $\begin{array}{l}\text { Poor } \\
\text { quality }\end{array}$ \\
\hline $\begin{array}{l}\text { Crehan } \\
\text { et al. [24] }\end{array}$ & $\begin{array}{l}\text { Quasi-experimental } \\
\text { study comparing } \\
\text { nurses' assessments } \\
\text { with new decision- } \\
\text { aid with a paediatri- } \\
\text { cian's assessment }\end{array}$ & $\begin{array}{l}57 \text { neonates who } \\
\text { received joint } \\
\text { assessments by } \\
\text { nurses and } \\
\text { paediatrician, } 27 \\
\text { April to } 15 \text { June } \\
2015\end{array}$ & $\begin{array}{l}\text { Zomba } \\
\text { District } \\
\text { Hospital, } \\
\text { Malawi }\end{array}$ & Secondary & $\begin{array}{l}\text { Low-cost } \\
\text { standalone } \\
\text { system- } \\
\text { Pumani }\end{array}$ & $\begin{array}{l}\text { Poor } \\
\text { quality }\end{array}$ \\
\hline $\begin{array}{l}\text { Fulton and } \\
\text { Lavalette } \\
{[25]}\end{array}$ & $\begin{array}{l}\text { Pre and post study } \\
\text { with follow-up } 6 \\
\text { months after inter- } \\
\text { ventions introduced }\end{array}$ & $\begin{array}{l}58 \text { neonates in } \\
\text { October } 2012 \text { and } \\
55 \text { neonates in } \\
\text { February } 2013\end{array}$ & $\begin{array}{l}\text { Felege } \\
\text { Hiwot } \\
\text { Referral } \\
\text { Hospital, } \\
\text { Ethiopia }\end{array}$ & Tertiary & $\begin{array}{l}\text { Improvised } \\
\text { water bottle } \\
\text { system }\end{array}$ & $\begin{array}{l}\text { Poor } \\
\text { quality }\end{array}$ \\
\hline $\begin{array}{l}\text { Gondwe } \\
\text { et al. [26] }\end{array}$ & $\begin{array}{l}\text { Observational } \\
\text { phenomenological } \\
\text { study with in-depth } \\
\text { semi-structured } \\
\text { interviews }\end{array}$ & $\begin{array}{l}12 \text { caregivers of } \\
\text { infants in Chatinkha } \\
\text { nursery ( } 0-28 \text { days) } \\
\text { and paediatric } \\
\text { nursery ( } 0-6 \\
\text { months) that } \\
\text { improved on } \\
\text { bCPAP January to } \\
\text { February } 2015\end{array}$ & $\begin{array}{l}\text { Queen } \\
\text { Elizabeth } \\
\text { Central } \\
\text { Hospital, } \\
\text { Malawi }\end{array}$ & Tertiary & $\begin{array}{l}\text { Low-cost } \\
\text { standalone } \\
\text { system- } \\
\text { Pumani }\end{array}$ & $\begin{array}{l}\text { Poor } \\
\text { quality }\end{array}$ \\
\hline $\begin{array}{l}\text { Kawaza } \\
\text { et al. [5], } \\
\text { Chen et al. } \\
\text { [27] }\end{array}$ & $\begin{array}{l}\text { Quasi-experimental } \\
\text { study with } \\
\text { allocation to CPAP } \\
\text { based on } \\
\text { availability of } \\
\text { equipment [5] with } \\
\text { an economic } \\
\text { evaluation [28] }\end{array}$ & $\begin{array}{l}87 \text { neonates ( } 62 \\
\text { bCPAP and } 25 \\
\text { nasal oxygen) over } \\
\text { a } 10 \text { month period } \\
\text { from January } 2012 \\
\text { to October } 2012\end{array}$ & $\begin{array}{l}\text { Queen } \\
\text { Elizabeth } \\
\text { Central } \\
\text { Hospital, } \\
\text { Malawi }\end{array}$ & Tertiary & $\begin{array}{l}\text { Low-cost } \\
\text { standalone } \\
\text { system- } \\
\text { Pumani }\end{array}$ & Fair quality \\
\hline McAdams & Descriptive case & 21 neonates & Kiwoko & Secondary & Improvised & Fair quality \\
\hline
\end{tabular}


Table 3 Studies included in the review (Continued)

\begin{tabular}{|c|c|c|c|c|c|c|}
\hline Reference & Research design & Sample & Location & $\begin{array}{l}\text { Facility } \\
\text { level }\end{array}$ & Device used & $\begin{array}{l}\text { Quality } \\
\text { assessment }\end{array}$ \\
\hline et al. [29] & $\begin{array}{l}\text { series of neonates } \\
\text { who received nasal } \\
\text { bubble CPAP }\end{array}$ & $\begin{array}{l}\text { starting }<3 \text { days of } \\
\text { age in NICU from } \\
\text { January to June } \\
2012\end{array}$ & $\begin{array}{l}\text { Hospital, } \\
\text { Uganda }\end{array}$ & $\begin{array}{l}\text { (rural } \\
\text { referral } \\
\text { hospital) }\end{array}$ & $\begin{array}{l}\text { water bottle } \\
\text { system }\end{array}$ & \\
\hline $\begin{array}{l}\text { Myhre } \\
\text { et al. [12] }\end{array}$ & $\begin{array}{l}\text { Pre and post } \\
\text { introduction of } \\
\text { bCPAP } \\
\text { retrospective chart } \\
\text { review }\end{array}$ & $\begin{array}{l}\text { All preterm infants } \\
\text { diagnosed with } \\
\text { RDS consisting of } \\
46 \text { infants enrolled } \\
\text { from } 1 \text { November } \\
2007 \text { to } 30 \text { April } \\
2009 \text { before and } 72 \\
\text { infants enrolled } \\
\text { from } 1 \text { November } \\
2009 \text { to } 30 \text { April } \\
2011 \text { after } \\
\text { introduction of } \\
\text { bCPAP }\end{array}$ & $\begin{array}{l}\text { AIC Kijabe } \\
\text { Hospital, } \\
\text { Kenya }\end{array}$ & $\begin{array}{l}\text { Secondary } \\
\text { (rural } \\
\text { referral } \\
\text { hospital) }\end{array}$ & $\begin{array}{l}\text { Improvised } \\
\text { water bottle } \\
\text { system }\end{array}$ & Fair quality \\
\hline $\begin{array}{l}\text { Nabwera } \\
\text { et al. [30] }\end{array}$ & $\begin{array}{l}\text { Observational cross- } \\
\text { sectional survey } \\
\text { with a structured } \\
\text { assessment tool } \\
\text { and qualitative key } \\
\text { informant inter- } \\
\text { views and focus } \\
\text { group discussions }\end{array}$ & $\begin{array}{l}39 \text { neonates who } \\
\text { received bubble } \\
\text { CPAP between } \\
\text { March and May } \\
\text { 2017; } 19 \text { (of 23) } \\
\text { tertiary level } \\
\text { hospitals in Kenya } \\
\text { surveyed }\end{array}$ & $\begin{array}{l}\text { Multiple } \\
\text { locations, } \\
\text { Kenya }\end{array}$ & $\begin{array}{l}\text { Tertiary } \\
\text { level } \\
\text { hospitals }\end{array}$ & $\begin{array}{l}\text { Majority (93\%) } \\
\text { used } \\
\text { commercial } \\
\text { bubble CPAP } \\
\text { systems }\end{array}$ & Fair quality \\
\hline $\begin{array}{l}\text { Nahimana } \\
\text { et al. [31] }\end{array}$ & $\begin{array}{l}\text { Observational } \\
\text { retrospective chart } \\
\text { review of all } \\
\text { newborns admitted } \\
\text { to neonatal units in } \\
\text { three rural hospitals }\end{array}$ & $\begin{array}{l}43 \text { infants initiated } \\
\text { on bubble CPAP } \\
\text { admitted between } \\
1 \text { February to } 31 \\
\text { October } 2013 \text { ( } 136 \\
\text { preterm and very } \\
\text { low birthweight } \\
\text { admitted overall) }\end{array}$ & $\begin{array}{l}\text { Butaro, } \\
\text { Kirehe and } \\
\text { Rwinkwavu } \\
\text { District } \\
\text { Hospitals, } \\
\text { Rwanda }\end{array}$ & $\begin{array}{l}\text { Secondary } \\
\text { (rural } \\
\text { district } \\
\text { hospitals) }\end{array}$ & $\begin{array}{l}\text { Bubble CPAP } \\
\text { system not } \\
\text { described }\end{array}$ & Fair quality \\
\hline $\begin{array}{l}\text { Ntigurirwa } \\
\text { et al. [32] }\end{array}$ & $\begin{array}{l}\text { Pre and post clinical } \\
\text { audits with follow- } \\
\text { up } 18 \text { months after } \\
\text { interventions } \\
\text { introduced }\end{array}$ & $\begin{array}{l}365 \text { infants in the } \\
\text { first } 18 \text { months of } \\
\text { introduction } \\
\text { between February } \\
2012 \text { and January } \\
2014\end{array}$ & $\begin{array}{l}\text { Two } \\
\text { university } \\
\text { hospitals } \\
\text { and two } \\
\text { district } \\
\text { hospitals, } \\
\text { Rwanda }\end{array}$ & $\begin{array}{l}\text { Tertiary } \\
\text { and } \\
\text { secondary }\end{array}$ & $\begin{array}{l}\text { Commercial } \\
\text { bubble CPAP } \\
\text { system- } \\
\text { Fisher Paykel }\end{array}$ & Fair quality \\
\hline $\begin{array}{l}\text { Okonkwo } \\
\text { and Okolo } \\
\text { [33] }\end{array}$ & $\begin{array}{l}\text { Observational cross- } \\
\text { sectional survey ad- } \\
\text { ministered to at- } \\
\text { tendees during the } \\
2015 \text { Paediatric As- } \\
\text { sociation of Nigeria } \\
\text { Conference } \\
\text { (PANCONF) }\end{array}$ & $\begin{array}{l}237 \text { questionnaires } \\
\text { returned by doctors } \\
\text { and nurses }\end{array}$ & $\begin{array}{l}54 \text { health } \\
\text { facilities } \\
\text { from six } \\
\text { geopolitical } \\
\text { regions of } \\
\text { Nigeria }\end{array}$ & $\begin{array}{l}\text { Mostly } \\
\text { public } \\
(87 \%) \\
\text { tertiary } \\
\text { hospitals } \\
(76 \%)\end{array}$ & $\begin{array}{l}\text { Improvised } \\
\text { water bottle } \\
\text { system vs } \\
\text { commercial } \\
\text { bubble CPAP } \\
\text { system- } \\
\text { Fisher Paykel }\end{array}$ & $\begin{array}{l}\text { Poor } \\
\text { quality }\end{array}$ \\
\hline $\begin{array}{l}\text { Olayo et al. } \\
\text { [28] }\end{array}$ & $\begin{array}{l}\text { Quasi-experimental } \\
\text { study that } \\
\text { compared } \\
\text { knowledge and skill } \\
\text { of first and second- } \\
\text { generation health } \\
\text { professionals } \\
\text { trained }\end{array}$ & $\begin{array}{l}37 \text { ( } 16 \text { nurses, } 21 \\
\text { physicians, medical/ } \\
\text { clinical officers) } \\
\text { first-generation } \\
\text { trained July } 2014 \text { to } \\
\text { August } 2015 \text { and } \\
40 \text { (19 nurses, } 21 \\
\text { physicians, medical/ } \\
\text { clinical officers) sec- } \\
\text { ond generation }\end{array}$ & $\begin{array}{l}\text { Multiple } \\
\text { locations, } \\
\text { Kenya }\end{array}$ & Tertiary & $\begin{array}{l}\text { Commercial } \\
\text { bubble CPAP } \\
\text { system- } \\
\text { DeVilbiss } \\
\text { IntelliPAP }\end{array}$ & $\begin{array}{l}\text { Poor } \\
\text { quality }\end{array}$ \\
\hline $\begin{array}{l}\text { van den } \\
\text { Heuvel } \\
\text { et al. [34] }\end{array}$ & $\begin{array}{l}\text { Descriptive case } \\
\text { series of neonates } \\
\text { who received nasal } \\
\text { bubble CPAP }\end{array}$ & $\begin{array}{l}11 \text { neonates during } \\
\text { a } 7 \text {-week introduc- } \\
\text { tion period from } 11 \\
\text { March to } 27 \text { April } \\
2008\end{array}$ & $\begin{array}{l}\text { Queen } \\
\text { Elizabeth } \\
\text { Central } \\
\text { Hospital, } \\
\text { Malawi }\end{array}$ & Tertiary & $\begin{array}{l}\text { Improvised } \\
\text { water bottle } \\
\text { system }\end{array}$ & Fair quality \\
\hline
\end{tabular}


standards of existing care [5, 21, 24, 28]. All four case-control intervention studies were quasi-experimental and there were no randomized controlled trials.

Of the 17 studies included in this review, six (35\%) used improvised water bottle systems, five (29\%) used low-cost standalone systems, two (12\%) used commercial bubble CPAP system and four (24\%) did not describe the system used or covered a combination of different types of devices. Four out of the five low-cost standalone systems used the Pumani bubble CPAP device, which was developed in Malawi [5, 23, 24, 26], and one study used politeCPAP, which was recently developed in Nigeria [21]. DeVilbiss IntelliPAP [28] and Fisher Paykel [32] bubble CPAP systems were the two commercial versions used. Most studies were conducted in tertiary level hospitals (11 studies; 65\%), with four (24\%) conducted in secondary level rural referral or district hospitals and two (12\%) included both tertiary and district hospitals. Studies were largely clustered in East African countries, Malawi and Nigeria. All the studies were published 2011 or afterwards.

\section{Device characteristics}

The device characteristics that promoted the use of bubble CPAP included the fact that it was simple to use compared with mechanical ventilation and that it was affordable and low maintenance $[19,20,22]$. Pricing ranged from US\$2 for a low-cost, improvised water bottle system made from locally available materials, US $\$ 350$ for a low-cost standalone unit developed in Malawi, to US\$2000 for a standalone unit including twin air compressors, temperature-controlled gas delivery and integrated pulse oximeter developed in Nigeria [5, 19-22, 27, 33].

Two studies, both from tertiary facilities in Nigeria, raised the concern that efficacy of bubble CPAP may be limited to mild to moderate respiratory distress and less complex cases $[19,20]$. These studies found that the majority of the newborns that did not respond to CPAP had a high Downes' score, which marks respiratory distress severity, and had a very (less than $1500 \mathrm{~g}$ ) or extremely (less than $1000 \mathrm{~g}$ ) low birthweight or other severe conditions $[19,20]$. Extremely low-birthweight newborns are at heightened risk for neonatal hypothermia and one study demonstrated that a bubble CPAP system with temperature-controlled gas delivery had the potential to reduce the risk of neonatal hypothermia, especially with this population [21].

\section{Training and staffing}

An important barrier for the implementation of bubble CPAP was around understaffing of neonatal units. As discussed in five studies, a lack of adequate staffing may limit the capacity for care, especially if existing workloads were already substantial $[24,25,29$, 32, 34]. An early study of bubble CPAP in Malawi found that there were only two nurses available for an average of 30 neonates [34]. Understaffing was associated with limited availability for training, which was compounded with other challenges such as high turnover of nurses and doctors necessitating repeated trainings of new staff [25, $28,30-32]$. Consequently, studies noted gaps in the training that was available. A study in Nigeria found that $44 \%$ of respondents were untrained in the use of bubble CPAP even though the same respondents reported that CPAP was used in $72 \%$ of their facilities [33]. 
Additionally, four studies described challenges around motivation and leadership [25, 30-32]. Researchers from a study conducted in Ethiopia noted the challenge of poor motivation as nurses did not appear to be interested in practising what they had learned in trainings [25]. Lack of motivation was linked to poor accountability, understaffing and frequent rotations by medical and nursing leadership [25, 32]. Additionally, one study found that local nurses did not understand English well, which presented a communication barrier with doctors who conducted medical meetings and ward rounds in English [25]. Good leadership by hospital management who perceived neonatal care as a priority was identified as an important facilitating factor for bubble CPAP implementation in 19 tertiary level facilities across Kenya [30].

Four studies highlighted the importance of regular and interactive training and that it could serve as a facilitator to implementation [24, 25, 28, 31]. The effective training used a wide range of methods including comprehensive presentations on respiratory physiology, indications to initiate bubble CPAP, contraindications and monitoring complemented by instructional videos, the use of case examples, simulation scenarios with mannequins and real-time supervision and utilization of bubble CPAP on an infant [24, 25, 28, 31]. Provider-to-provider clinical mentorship models supported training efforts, especially when clinical mentors were trained in how to train others to use bubble CPAP [28, 30, 31]. Experience sharing trips to effective neonatal units and intermittent refresher trainings were helpful in supporting knowledge and skill development; this built motivation and morale as health providers regarded it as an investment in their professional capacities [25, 31]. One study recommended investing by training the nurses who across profession generally remain on the ward compared to doctors who may move around the hospital or between hospitals [25]. Another study recommended resources be allocated to introducing long-term clinicians to reinforce training [32]. To build momentum and motivation, two studies used a combination of external consultants with local clinicians to provide training [31, 34].

\section{Initiation, monitoring and weaning}

Four studies discussed barriers to commencement of CPAP [20, 23, 31, 34]. Challenges around initiation highlighted that gaps in the correct identification of early/mild signs of respiratory distress [31] and the reluctance of nurses to initiate CPAP due to short staffing and/or desire to consult with a doctor first [34] were associated with a delay in initiating bubble CPAP, which was ultimately associated with less optimal outcomes [5]. Three studies further highlighted that regular monitoring is required to prevent and manage complications, such as nasal prong-related complications and "CPAP belly syndrome" [ 5 , 20, 23]. Additionally, two studies discussed the challenges around weaning, including knowing when to wean, especially when human resources were limited [29], and the need to monitor closely after weaning to ensure the neonate is not desaturating [19].

Decision aids were described as potential facilitators to bubble CPAP use, including a clinical algorithm to aid in deciding to initiate [24] and using a respiratory severity score to monitor respiratory distress [29]. No potential facilitators for the weaning process were presented.

\section{Caregivers}

Three studies, including two from Malawi and one from Kenya, discussed barriers to implementation around engaging caregivers $[23,26,30]$. Brown et al. found that parents in Malawi 
may be reluctant to allow infants to receive oxygen therapy because the need for oxygen was considered to cause poor outcomes [23]. A qualitative study researching caregiver experiences at a tertiary hospital in Malawi found that there were gaps in consenting parents before starting bubble CPAP, particularly since there was limited visiting hours to the neonatal intensive care unit (NICU) and caregivers often found their newborn already commenced on bubble CPAP [26]. Information about bubble CPAP was poorly provided to all caregivers, including the mother and close family members [26]. The caregivers' experiences also shared concerns on how bubble CPAP may complicate mother-infant interactions [26]. It was noted that mothers were afraid to hold their infants because they were worried that they would not be able to see their child's face and that the device would interrupt skin-to-skin contact [26]. A study from Kenya highlighted that peer support from the caregivers of newborns that had survived after being put on bubble CPAP was a particularly powerful opportunity to educate parents and guardians who are unsure about the system [30].

\section{Supplies and equipment}

Three studies, all from Nigeria, discussed using appropriate and locally available equipment as facilitators for bubble CPAP implementation [19, 20, 22]. Appropriate equipment focused on nasal prongs and the importance of snug-fitting and soft nasal prongs to prevent nasal damage $[19,20]$.

Five studies, however, also identified how a reliable supply and availability of equipment was an implementation challenge [5, 23, 30,32,34]. Ancillary equipment, such as oxygen concentrators, was an issue; even though the low-cost standalone bubble CPAP model was developed for low-resource settings and was low maintenance, the oxygen concentrators associated with the device were not [5]. In one study, $40 \%$ of oxygen concentrators failed due to line voltage spikes [5]. Cost of disposable nasal prongs was also identified as a barrier in resourceconstrained settings as was the availability of CPAP machines [5, 23, 34]. A Malawian study by Kawaza et al. noted that $31 \%(n=12)$ of the neonates died when the CPAP system was occupied and the newborn did not receive CPAP [5]. Studies also highlighted diversity on the health landscape as different CPAP machines caused challenges in training, setup and maintenance [32]. A recent study from Kenya found that most bubble CPAP systems across the 19 tertiary level facilities evaluated were commercial versions donated by international partners. These devices encountered problems with maintenance as donor projects completed and support was withdrawn [30]. Additionally, inadequate infrastructure was associated with lower staff morale and motivation to use bubble CPAP [30] (Table 4).

\section{Barriers and facilitators of bubble CPAP by health facility and device type}

Across the multiple settings and device types, understaffed neonatal units, high turnover of staff and low staff motivation and morale to use bubble CPAP were common barriers. Common facilitators were clinical mentorship and regular, interactive training. Decision aids to support the initiation and monitoring respiratory distress were highlighted as facilitators in secondary level facilities $[24,29]$. Affordability was highlighted as a facilitator in both improvised water bottle systems and low-cost standalone models [5, 20-22, 27]. Studies focusing on improvised water bottle systems highlighted the benefit of being able to use locally available materials to manufacture the bubble CPAP device, yet a perceived barrier remains because most improvised water bottle systems and standalone models do not heat or humidify the air 
Table 4 Implementation factors

\begin{tabular}{|c|c|c|}
\hline Topic & Facilitators & Barriers \\
\hline Device & $\begin{array}{l}\text { - Simple to use, affordable and low maintenance for } \\
\text { low-resource settings. } \\
\text { - A temperature-controlled gas circuit may reduce } \\
\text { the risk of hypothermia especially in extremely low- } \\
\text { birthweight babies. }\end{array}$ & $\begin{array}{l}\text { - Efficacy may be limited to mild to } \\
\text { moderate respiratory distress and less } \\
\text { effective with severe cases. }\end{array}$ \\
\hline $\begin{array}{l}\text { Training } \\
\text { and staffing }\end{array}$ & $\begin{array}{l}\text { - Regular and interactive training with intermittent } \\
\text { refresher trainings. } \\
\text { - Clinical mentorship with training on how to train } \\
\text { others to use bubble CPAP. } \\
\text { - Investing in nurses dedicated to the nursery. } \\
\text { - Clinicians that stay longer term in the nursery. } \\
\text { - Combination of external consultant with local } \\
\text { clinicians as trainers. } \\
\text { - Health facility management that prioritized } \\
\text { neonatal care. }\end{array}$ & $\begin{array}{l}\text { - Understaffed neonatal units limit the } \\
\text { capacity for care. } \\
\text { - Staffing shortages exacerbated by } \\
\text { healthcare provider strikes in some } \\
\text { locations. } \\
\text { - High turnover of nurses and doctors } \\
\text { necessitated repeated training of new } \\
\text { staff. } \\
\text { - Lack of motivation and accountability. } \\
\text { - Gaps in training as many nurses and } \\
\text { doctors are untrained in bubble CPAP. } \\
\text { - Communication barriers between } \\
\text { doctors and nurses. }\end{array}$ \\
\hline Initiation & $\begin{array}{l}\text { - Decision-making aided by clinical algorithm that is } \\
\text { clearly posted by the machine. }\end{array}$ & $\begin{array}{l}\text { - Gaps in correct identification of early and } \\
\text { mild signs of distress. } \\
\text { - Reluctance of nurses to initiate while } \\
\text { short-staffed at night and without con- } \\
\text { sulting a clinician. } \\
\text { - Overtightening the chin strap can lead } \\
\text { to facial swelling. }\end{array}$ \\
\hline Monitoring & $\begin{array}{l}\text { - Appropriate and regular monitoring. } \\
\text { - Monitoring with pulse oximetry. } \\
\text { - Monitoring respiratory distress with respiratory } \\
\text { severity score. }\end{array}$ & $\begin{array}{l}\text { - Complications such as CPAP belly } \\
\text { syndrome and mucosal drying require } \\
\text { regular monitoring and actions to } \\
\text { prevent. }\end{array}$ \\
\hline Weaning & None discussed. & $\begin{array}{l}\text { - Knowing when to wean, especially when } \\
\text { resources are limited. } \\
\text { - A need to monitor closely after weaning } \\
\text { to ensure the infant is not desaturating. }\end{array}$ \\
\hline Caregivers & $\begin{array}{l}\text { - Peer support from caregivers with positive } \\
\text { experiences with bubble CPAP use on their own } \\
\text { newborns. }\end{array}$ & $\begin{array}{l}\text { - Local beliefs that the oxygen led to poor } \\
\text { outcomes. } \\
\text { - Poorly providing information to } \\
\text { caregivers and gaps in consenting } \\
\text { parents before starting bubble CPAP. } \\
\text { - Bubble CPAP may complicate mother- } \\
\text { infant interaction as mothers were afraid } \\
\text { to hold babies, unable to see their in- } \\
\text { fant's faces and interrupted skin-to-skin } \\
\text { contact. }\end{array}$ \\
\hline $\begin{array}{l}\text { Supplies } \\
\text { and } \\
\text { equipment }\end{array}$ & $\begin{array}{l}\text { - Appropriate snug-fitting nasal prongs. } \\
\text { - Soft nasal prongs. } \\
\text { - Use of locally available materials. }\end{array}$ & $\begin{array}{l}\text { - Cost of disposable nasal prongs. } \\
\text { - Oxygen concentrators not always } \\
\text { available. } \\
\text { - CPAP machines not always available. } \\
\text { - Different machines cause challenges in } \\
\text { training, set up and maintenance. } \\
\text { - Poor equipment maintenance once } \\
\text { donors withdraw support. }\end{array}$ \\
\hline
\end{tabular}

being provided to the newborn [5, 21, 23]. Additionally, low-cost standalone models highlighted the benefit of low maintenance, while inadequate maintenance was cited as a barrier especially for commercial models $[5,21,30]$.

\section{Efficacy and safety of bubble CPAP by health facility and device type} Nine of the 17 studies (53\%) presented novel data on survival to discharge rates. Survival to discharge rates with bubble CPAP varied widely between studies, ranging from 
49 to $85 \%$ in tertiary hospitals $[20,22,30,34]$ and 42 to $85 \%$ in rural district level referral hospitals $[12,29,31]$. Additionally, survival to discharge rates for the Pumani device which was noted in two studies ranged from 56 to 71\% [5,24] and for the improvised water bottle system, the survival to discharge rate ranged from 52 to $85 \%$ over five studies [12, 20, 22, 29, 34]. One study that did not describe the bubble CPAP system they used reported a $42 \%$ survival rate and another study that surveyed multiple hospitals where commercial models were the most frequently utilized device reported a $49 \%$ survival rate [30]. Mechanical ventilation was not available on site in eight of the nine studies and only one of these eight had the option of referring to a higher-level facility with mechanical ventilation [31]. A survey in Kenya found that mechanical ventilation was only available in $37 \%$ tertiary level hospitals across the nation [30].

Across the various forms of bubble CPAP systems, there were no major complications reported. Studies highlighted that this may be in part due to a lack of necessary resources to assess for these complications such as routine $\mathrm{x}$-rays, cranial ultrasounds or autopsies to ascertain the cause of death [5, 23, 30]. Nasal and facial irritation was the most commonly reported minor complication across different bubble CPAP systems and facility levels. For example, nasal irritation was reported in $14 \%$ of cases in a secondary level facility with an improvised water bottle system [29], 13\% of neonates initially started on bubble CPAP in a tertiary level facility with a low-cost standalone model (Pumani) [5] and 13\% of infants in a multi-sited study with both tertiary and secondary level facilities with a commercial model [32]. Nasal irritation was not well defined but some studies described it as slight soreness, abrasions, swelling, redness and mucosal erosion [29, 34].

\section{Discussion}

The purpose of the review was to evaluate the barriers and facilitators to implementing bubble CPAP for newborn care at sub-Sahara African health facilities. Reliable availability of equipment, difficulties engaging and informing caregivers and staffing shortages were frequently mentioned barriers to the implementation of bubble CPAP. Understaffed neonatal units and high turnover of nurses and doctors limited capacity for care and was associated with gaps in training, which subsequently impacted initiation, monitoring and weaning. Provider-to-provider clinical mentorship models were identified as frequently mentioned facilitators of bubble CPAP implementation within the context of staffing shortages and high staff turnovers as they helped to address challenges in the aim to formally train and retain trained staff in neonatal units. Affordability and cost-effectiveness were also highlighted as important facilitators, especially for low-cost standalone units and improvised models. A cost-effectiveness study on the low-cost standalone unit from Malawi found an average cost per patient on bubble CPAP was US\$29.29 compared to US\$57.78 per patient on nasal oxygen [27]. Mechanical ventilation costs in LMICs was not available, though a study in the USA found that costs for a preterm infant $\leq 32$ weeks gestation on mechanical ventilation in the USA was US\$51,000-209,000 [35].

A previous review revealed that bubble CPAP may reduce the need for mechanical ventilation in LMICs [8]. This is of great importance in resource-constrained contexts where mechanical ventilation is not often available due to high costs, maintenance demands and the need for highly trained staff. However, to use mechanical ventilation as 
a comparator to evaluate bubble CPAP excludes the most resource-constrained contexts where mechanical ventilation is unavailable. Such criteria would exclude almost all of the studies in the present review, for example. The tertiary hospitals in subSaharan Africa covered by the studies in this review frequently lacked the resources for mechanical ventilation, which suggests that differences between LMICs may be just as important as those between HICs and LMICs. A focus on low-resource settings is particularly important as bubble CPAP is being scaled-up to secondary level rural district hospitals in sub-Saharan Africa where contexts may be even more resourceconstrained.

Secondary objectives of this review investigated how different facility levels and types of bubble CPAP systems may impact utilization, expanding on previous reviews on the efficacy of CPAP in LMICs where multiple types of nasal CPAP systems and health facility levels were grouped together $[8,9]$. Few major complications were reported regardless of the system type and facility setting and survival to discharge rates appeared to differ more between studies than between the device used and the setting. The studies in this review, however, revealed contextual differences that could influence implementation and sustainability. Though many studies were conducted in tertiary level facilities, two of the four studies completed in secondary level facilities highlighted how decision-making aids were feasible and helpful to support nurses' decision to initiate an infant on bubble CPAP and to monitor the neonates' level of respiratory distress. The discussion around decision-making aids was absent in studies conducted in tertiary level facilities perhaps in part because the tertiary level facilities had full-time paediatric specialists on staff to make major decisions whereas the nurseries in secondary level facilities were often nurse-led [31].

Sub-Saharan Africa is unique in the global CPAP landscape for the development of novel, low-cost standalone bubble CPAP systems in an attempt to reduce cost and bridge the gap between conventional commercial models and locally improvised systems. Though less expensive than mechanical ventilation, conventional commercial bubble CPAP systems cost between US $\$ 6000$ and 18,000, which means that they continue to be unaffordable for resource-constrained hospitals in sub-Saharan Africa [5, 21, 23]. Additionally, most commercial systems available in these settings were donated without the means to maintain them sustainably [30]. Both studies in the review using conventional commercial systems involved external partners that brought in foreign consultants to initially train and set up the programme [28, 32]. Maintenance and programme sustainability for the commercial systems were key barriers after the donors withdrew support and the presence of different types of bubble CPAP system made it challenging for staff to be adequately trained for all the different devices and have all of the components to set up and expertise in equipment maintenance for the various systems [30, 32]. With concerns around equipment maintenance and sustainability for the commercial bubble CPAP system, both low-cost standalone models highlighted the affordability and low maintenance of their systems as valuable facilitators to their implementation in sub-Saharan Africa [5, 21].

While innovative, low-cost, standalone models sought to present solutions to barriers of affordability and maintenance, studies also revealed the basic necessity for a supportive health system environment. Understaffed neonatal units, gaps in training and shortages of ancillary supplies, such as disposable nasal prongs and oxygen concentrators, 
continued to provide significant challenges. In this, the situation with bubble CPAP is not unique. The need for adequate supplies, financing, trained health workers and service delivery coherence within and between health facilities has also been highlighted as health system barriers in the scale-up of other maternal and child health interventions across sub-Saharan Africa [36-38]. These barriers hinder the sustainability of health interventions after implementation, particularly in sub-Saharan Africa where there is a disproportionate share of the global disease burden and weak health systems sensitive to the fluctuations of donor-funding [37]. For the implementation of bubble CPAP and other neonatal care innovations, there is a need to consider health systems and understand the challenges a low-resource setting presents in providing care for a neonate including the processes involved and other factors that may impact the newborn's health. A retrospective analysis of the non-randomized controlled trial in Malawi, for example, found that for survival outcomes, bubble CPAP was not sufficient as a single intervention if a preterm neonate was hypothermic in addition to respiratory distress [39]. The persistently high mortality rates reported in the neonatal bubble CPAP studies in this review underlines the importance of health system strengthening and the human and material resources required to improve care outcomes for small and sick newborns. Even though the study population was different, the study by McCollum et al. illustrates this point further [40]. In a large trial involving 644 older infants and children up to 6 years of age, McCollum et al. found no reduction in hospital mortality with bubble CPAP use (Fisher \& Paykel commercial device) in a rural Malawian hospital that did not have daily physician supervision [40]. For effective implementation of bubble CPAP, comprehensive quality care is needed in addition to appropriate technologies.

One limitation of this review is the exclusion of non-English texts, which may have excluded some studies. A strength of this review includes the use of multiple reviewers, the searches on multiple databases and grey literature and use of quality assessments. Similar to previous systematic reviews on CPAP and bubble CPAP across LMICs, the present review did not find any randomized controlled trials $[8$, 9]. However, considering the strong recommendation for its use with preterm newborns in respiratory distress by the WHO [7] and neonatal experts in the field [41], it is unethical to withhold treatment in order to conduct an RCT comparing bubble CPAP and nasal oxygen therapy. There are grounds, however, to suggest that other RCTs would be beneficial in developing a robust evidence-base for the facilitators, such as an RCT assessing survival outcomes from bubble CPAP use in addition to provided nursing utilization guidelines compared to bubble CPAP with no utilization guidelines.

The quality assessment revealed that many studies had considerable risk of biases (see Additional file 2) but unlike the previous systematic reviews published on bubble CPAP $[8,9]$, the primary purpose of this review was not to evaluate efficacy. Some of the implementation challenges around staffing shortages, training gaps and missing data may introduce bias into studies; however, from an implementation science perspective, they importantly revealed health system barriers and facilitators. Research that focuses on barriers and facilitators of implementation and utilization as the primary objective is needed, especially to understand the views of health professionals that interact with bubble CPAP provisioning and oversight. 


\section{Conclusion}

To accelerate progress towards the reduction of neonatal mortality in sub-Saharan Africa, improvements in neonatal care is needed, especially for premature newborns. There has been increasing interest in the utilization of bubble CPAP in resourceconstrained health facilities in sub-Saharan Africa to improve outcomes for neonates with respiratory distress. However, the implementation of bubble CPAP is not without its challenges. While bubble CPAP may be seemingly streamlined and uncomplicated compared to mechanical ventilation, even simple and innovative technologies require supportive health systems for effective implementation and utilization. Future research into health system barriers and facilitators of bubble CPAP implementation is paramount for practical purposes, especially in low-resource and rural contexts.

\section{Supplementary information}

Supplementary information accompanies this paper at https://doi.org/10.1186/s40985-020-00124-7.

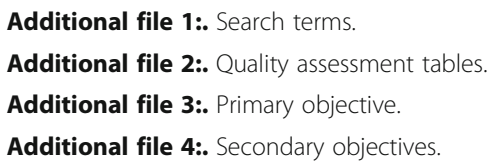

\section{Acknowledgement}

This manuscript is part of the "Integrating a neonatal healthcare package for Malawi" project within the Innovating for Maternal and Child Health in Africa (IMCHA) initiative. The authors would like to express their gratitude to the IMCHA team for their support.

\section{Authors' contributions}

MWK contributed to the conception of the research protocol, study design, literature review, data extraction, data analysis and interpretation; drafted the original paper; and coordinated the feedback to revise the paper. CRW and TH contributed to the literature review, data analysis and interpretation and the quality assessment and provided critical feedback to all versions. MV and ALNM gave advice on the structure of the paper and critically reviewed all versions. QD, DMG and KK contributed to the conceptualization of the research project and its funding acquisition and critically reviewed all versions. In addition, KK supervised project activities. All authors have read and approved the manuscript.

\section{Funding}

"Integrating a neonatal healthcare package for Malawi" (IMCHA \#108030) is funded by the Canadian International Development Research Centre (IDRC) in partnership with Global Affairs Canada (GAC) and the Canadian Institutes for Health Research (CIHR).

\section{Availability of data and materials}

See Additional file 1 for search terms.

See Additional file 2 for quality assessment tables.

See Additional file 3 for primary objective tables.

See Additional file 4 for secondary objective tables.

Any additional data will be available upon request to the corresponding author

Ethics approval and consent to participate

Not applicable

Consent for publication

Not applicable

\section{Competing interests}

The authors declare that they have no competing interests.

\section{Author details}

${ }^{1}$ Department of Obstetrics and Gynaecology, BC Children's and Women's Hospital and University of British Columbia, Vancouver, Canada. 'Department of Pathology and Laboratory Medicine, BC Children's and Women's Hospital and University of British Columbia, Vancouver, Canada. ${ }^{3}$ Department of Pediatrics and Child Health, College of Medicine, University of Malawi, Blantyre, Malawi. ${ }^{4}$ School of Public Health and Family Medicine, Department of Health Systems and Policy, College of Medicine, University of Malawi, Blantyre, Malawi. ${ }^{5}$ Department of Paediatrics, Queen Elizabeth Central Hospital, Blantyre, Malawi. 
Received: 21 August 2019 Accepted: 7 April 2020

Published online: 28 April 2020

\section{References}

1. UNICEF. WHO, World Bank, United Nations. New York: Levels and trends in child mortality report 2018; 2018.

2. Mejía-Guevara I, Zuo W, Bendavid E, Li N, Tuljapurkar S. Age distribution, trends, and forecasts of under-5 mortality in 31 sub-Saharan African countries: a modeling study. Persson LÅ, editor. PLOS Med. 2019 Mar 12;16(3):e1002757.

3. Hug L, Sharrow D, Sun Y, Marcusanu A, You D, Mathers C, et al. Levels \& trends in child mortality child mortality report 2017 organizations and individuals involved in generating country-specific estimates of child mortality United Nations Children's Fund Special thanks to the Technical Advisory Group of the UN IGME for providing technical guidance on methods for child mortality estimation. [cited 2018 Jun 21]; Available from: https://www.unicef.org/publications/files/ Child_Mortality_Report_2017.pdf.

4. Blencowe H, Cousens S, Oestergaard MZ, Chou D, Moller AB, Narwal R, et al. National, regional, and worldwide estimates of preterm birth rates in the year 2010 with time trends since 1990 for selected countries: a systematic analysis and implications. Lancet. 2012;379(9832):2162-72.

5. Kawaza K, Machen HE, Brown J, Mwanza Z, Iniguez S, Gest A, et al. Efficacy of a low-cost bubble CPAP system in treatment of respiratory distress in a neonatal ward in Malawi. PLoS One Jan Malawi Med J. 2014;299(283):e86327.

6. Mathai SS, Raju U, Kanitkar M. Management of respiratory distress in the newborn. Med J Armed Forces India. 2007; 63(3):269-72.

7. WHO recommendations on interventions to improve preterm birth outcomes. WHO [Internet]. 2016 [cited 2018 Jun 21]; Available from: http://www.who.int/reproductivehealth/publications/maternal_perinatal_health/preterm-birth-guideline/ en/.

8. Martin S, Duke T, Davis P. Efficacy and safety of bubble CPAP in neonatal care in low and middle income countries: a systematic review. Arch Dis Child Fetal Neonatal Ed. 2014 Nov 1;99(6):F495-504.

9. Thukral A, Sankar MJ, Chandrasekaran A, Agarwal R, Paul VK. Efficacy and safety of CPAP in low- and middle-income countries. J Perinatol. 2016:36:21-8.

10. Davis PG, Morley CJ, Owen LS. Non-invasive respiratory support of preterm neonates with respiratory distress: continuous positive airway pressure and nasal intermittent positive pressure ventilation. Semin Fetal Neonatal Med. 2009;14(1):14-20

11. Jensen EA, Chaudhary A, Bhutta ZA. Non-invasive respiratory support for infants in low- and middle-income countries. Semin Fetal Neonatal Med. 2016;21(3):181-8.

12. Myhre J, Immaculate M, Okeyo B, Anand M, Omoding A, Myhre L, et al. Effect of treatment of premature infants with respiratory distress using low-cost bubble CPAP in a rural african hospital. J Trop Pediatr. 2016;62(5):385-9.

13. Sanders D, Haines A. Implementation research is needed to achieve international health goals. PLoS Med. 2006 Jun;3(6): e186.

14. Falk M, Donaldsson S, Drevhammar T. Infant CPAP for low-income countries: an experimental comparison of standard bubble CPAP and the Pumani system. Ehrhardt H, editor. PLoS One. 2018;13(5):e0196683.

15. Sterne JA, Hernán MA, Reeves BC, Savović J, Berkman ND, Viswanathan M, et al. ROBINS-l: a tool for assessing risk of bias in non-randomised studies of interventions. BMJ. 2016;355:4919.

16. $\mathrm{NIH}$ National Heart $\mathrm{L}$ and BI. Development and use of study quality assessment tools | National Heart, Lung, and Blood Institute (NHLBI) [Internet]. [cited 2019 Jul 5]. Available from: https://www.nhlbi.nih.gov/health-topics/study-qualityassessment-tools.

17. Connolly MP, Haitsma G, Hernández AV, Vidal JE. Systematic review and meta-analysis of secondary prophylaxis for prevention of HIV-related toxoplasmic encephalitis relapse using trimethoprim-sulfamethoxazole. Pathog Glob Health. 2017;111(6):327-31.

18. Kinshella M-LW, Walker CR, Hiwa-Maliro T. Barriers and facilitators to implementing bubble CPAP to improve neonatal health in sub-Saharan Africa. PROSPERO 2018 CRD42018116082 Available from http//www.crd.york.ac.uk/PROSPERO/ display_record.php?|D=CRD42018116082.

19. Abdulkadir I, Abdullahi F. The Use of bubble nasal CPAP in the management of IRDS-a case report and literature review. CASE Rep Niger J Paed. 2013;40(3):303-6.

20. Abdulkadir I, Hassan L, Abdullahi F. Nasal bubble CPAP: one year experience in a neonatal unit of a tertiary health facility in Northwestern Nigeria. Vol. 22, The Nigerian Postgraduate Medical Journal. 2015.

21. Amadi HO, Okonkwo IR, Abiove IO, Abubakar AL, Olateju EK, Adesina $\mathrm{CT}$, et al. A new low-cost commercial bubble CPAP (bCPAP) machine compared with a traditional bCPAP device in Nigeria. Paediatr Int Child Health. 2019.

22. Audu L, Otuneye A, Mairami A, Mukhtar M. Improvised bubble continuous positive airway pressure (BCPAP) device at the National Hospital Abuja gives immediate improvement in respiratory rate and oxygenation in neonates with respiratory distress. Niger J Paediatr. 2014;42(1):12.

23. Brown J, Machen H, Kawaza K, Mwanza Z, Iniguez S, Lang H, et al. A high-value, low-cost bubble continuous positive airway pressure system for low-resource settings: technical assessment and initial case reports. Semple MG, editor. PLoS One. 2013;8(1):e53622.

24. Crehan C, Colbourn T, Heys M, Molyneux E. Evaluation of 'TRY': an algorithm for neonatal continuous positive airways pressure in low-income settings. Arch Dis Child. 2018 Aug;103(8):732-8.

25. Fulton C. Improving neonatal mortality in an Ethiopian referral hospital. BMJ Open Quality 2013;2:U202086.w1064. https://doi.org/10.1136/bmjquality.u202086.w1064.

26. Gondwe MJ, Gombachika B, Majamanda MD. Experiences of caregivers of infants who have been on bubble continuous positive airway pressure at Queen Elizabeth Central Hospital, Malawi: A descriptive qualitative study. Malawi Med J. 2017;29(1):10-5.

27. Chen A, Deshmukh AA, Richards-Kortum R, Molyneux E, Kawaza K, Cantor SB. Cost-effectiveness analysis of a low-cost bubble CPAP device in providing ventilatory support for neonates in Malawi - a preliminary report. BMC Pediatr. 2014 14(1):288. 
28. Olayo B, Kirigia CK, Oliwa JN, Agai N, Morris M, Benckert M, et al. Effective training-of-trainers model for the introduction of continuous positive airway pressure for neonatal and paediatric patients in Kenya. Paediatr Int Child Health. 2019.

29. McAdams RM, Hedstrom AB, DiBlasi RM, Mant JE, Nyonyintono J, Otai CD, et al. Implementation of bubble CPAP in a rural Ugandan neonatal ICU. Respir Care. 2015;60(3):437-45.

30. Nabwera $H$, Munguti M, Naimoi B, Mathai $M$, van den Broek N. Assessment of the use of continuous positive airway pressure (CPAP) in newborn care in Kenya. London; 2019.

31. Nahimana E, Ngendahayo M, Magge H, Odhiambo J, Amoroso CL, Muhirwa E, et al. Bubble CPAP to support preterm infants in rural Rwanda: a retrospective cohort study. BMC Pediatr. 2015;15(1):135.

32. Ntigurirwa P, Mellor K, Langer D, Evans M, Robertson E, Tuyisenge L, et al. A health partnership to reduce neonatal mortality in four hospitals in Rwanda. Global Health. 2017;13(1):28.

33. Okonkwo IR, Okolo A. Bubble CPAP in Nigerian tertiary hospitals. Patented and improvised. Niger J Paediatr. 2016 Oct 20;43(4):286.

34. Van Den Heuvel M, Blencowe H, Mittermayer K, Rylance S, Couperus A, Heikens GT, et al. Introduction of bubble CPAP in a teaching hospital in Malawi. Ann Trop Paediatr. 2011;31(1):59-65.

35. Hayman WR, Leuthner SR, Laventhal NT, Brousseau DC, Lagatta JM. Cost comparison of mechanically ventilated patients across the age span. J Perinatol. 2015;35(12):1020-6.

36. Enweronu-Laryea C, Dickson KE, Moxon SG, Simen-Kapeu A, Nyange C, Niermeyer S, et al. Basic newborn care and neonatal resuscitation: a multi-country analysis of health system bottlenecks and potential solutions. BMC Pregnancy Childbirth. 2015 [cited 2020 Mar 21];15(S2):S4. Available from: http://bmcpregnancychildbirth.biomedcentral.com/ articles/10.1186/1471-2393-15-S2-S4

37. Iwelunmor J, Blackstone S, Veira D, Nwaozuru U, Airhihenbuwa C, Munodawafa D, et al. Toward the sustainability of health interventions implemented in sub-Saharan Africa: a systematic review and conceptual framework. Vol. 11 , Implementation Science. BioMed Central Ltd.; 2016.

38. Puchalski Ritchie LM, Khan S, Moore JE, Timmings C, van Lettow M, Vogel JP, et al. Low- and middle-income countries face many common barriers to implementation of maternal health evidence products. J Clin Epidemiol. 2016;76:229-37.

39. Carns J, Kawaza K, Quinn MK, Miao Y, Guerra R, Molyneux E, et al. Impact of hypothermia on implementation of CPAP for neonatal respiratory distress syndrome in a low-resource setting. 2018;

40. McCollum ED, Mvalo T, Eckerle M, Smith AG, Kondowe D, Makonokaya D, et al. Bubble continuous positive airway pressure for children with high-risk conditions and severe pneumonia in Malawi: an open label, randomised, controlled trial. Lancet Respir Med. 2019;7(11):964-74.

41. Jensen EA, DeMauro SB, Kirpalani H. Has enough evidence accumulated to consider CPAP a first-line standard of care in developing countries? Arch Dis Child Fetal Neonatal Ed. 2014;99(6):F443-4.

\section{Publisher's Note}

Springer Nature remains neutral with regard to jurisdictional claims in published maps and institutional affiliations.

Ready to submit your research? Choose BMC and benefit from:
- fast, convenient online submission
- thorough peer review by experienced researchers in your field
- rapid publication on acceptance
- support for research data, including large and complex data types
- gold Open Access which fosters wider collaboration and increased citations
- maximum visibility for your research: over 100M website views per year
At BMC, research is always in progress.
Learn more biomedcentral.com/submissions

